Katarzyna Marta Pniewska

\title{
WYMIAR SPOŁECZNY KORPORACJI FINANSOWYCH W SYSTEMIE KAPITALISTYCZNYM
}

\section{Wprowadzenie}

Kapitalizm jest systemem ekonomicznym, który pojawił się po upadku feudalizmu. Opiera się na własności prywatnej, dążeniu do maksymalizacji zysku, a także na wolnym obrocie środkami produkcji, dobrami, usługami, pracą i kapitałem oraz wolnej konkurencji pomiędzy podmiotami. W idealnej postaci ceny kształtowane są przez procesy rządzące rynkiem. Kapitalizm według Sombarta jest określany poprzez czynność zawodową, racjonalność i indywidualizm, według Webera - poprzez racjonalnie zorganizowaną pracę i kalkulację rentowności, a według Schumpetera - poprzez siłę innowacyjnych i dynamicznych przedsiębiorstw ${ }^{1}$.

„Charakterystyczne dla kapitalizmu jest specyficzne zróżnicowanie wielkich grup społecznych na: pracowników, których głównym źródłem utrzymania jest praca najemna [...] oraz właścicieli kapitału - przedsiębiorców, posiadających odpowiednie środki w postaci kapitału obejmującego: aktywa finansowe, budynki, maszyny, środki transportu, ziemię. Współzależności występujące między tymi grupami nie mają charakteru wspartej przymusem zależności osobistej w formie poddaństwa feudalnego, ale przybierają postać ruchu okrężnego dochodów pieniężnych, zasobów wytwórczych oraz dóbr i usług”2. Pozycja społeczna jednostki określana jest poprzez zajmowane przez nią miejsce w procesie produkcji.

W kapitalizmie rząd ponosi odpowiedzialność za ład i porządek w państwie 3 . Sam A. Smith twierdził, że ochrona własności prywatnej gwarantowana przez rząd „W rzeczywistości polega na ochronie tych, którzy coś posiadają, przed tymi, którzy

\footnotetext{
1 Der Brockhaus, Wirtschaft: Betriebs- und Volkswirtschaft, Börse, Finanzen, Versicherungen und Steuern, F.A. Brockhaus GmbH, Lipsk-Mannheim 2008, s. 318.

2 http://encyklopedia.pwn.pl/haslo/3920039/kapitalizm.html (14.06.2012).

3 B.R. Scott, The Political Economy of Capitalism, „Harvard Business School Working Paper”, December 2006, Nr 07-037, s. 2.
} 
nic nie mają"4. Autor ujął w tych słowach wymiar kwestii społecznej tego systemu ekonomicznego, a właściwie jej brak.

Celem opracowania jest zestawienie zagadnień związanych z kapitalizmem oraz korporacjami finansowymi w celu refleksji nad konsekwencjami społecznymi ich działalności.

\section{Formy kapitalizmu}

W kapitalizmie szczególne znaczenie mają prawa rynkowe. W zależności od kierunku prowadzonej polityki podejmowane są próby modyfikacji tych procesów wzmacniające lub łagodzace wpływ na społeczeństwa. W tym celu stosowane mogą być $n p$. interwencjonizm, protekcjonizm, ograniczenia w wolnym obrocie towarami i usługami, nadawanie koncesji i zezwoleń, zdywersyfikowany system podatkowy zależny od rodzaju podmiotu albo kontrolę państwa nad systemem bankowym. Wobec tego istnieją następujące formy kapitalizmu: anglo-amerykański, europejski i nordycki. Różni autorzy podejmują próby definiowania faz kapitalizmu. Według Sombarta wyróżnia się kapitalizm: wczesny, przemysłowy i późny. Zgodnie z teorią marksistowską wyróżnia się kapitalizm: wczesny, konkurencyjny, monopolistyczny, imperialistyczny, monopolu państwowego ${ }^{5}$. Relacja między gospodarką realną i rozwojem na rynkach finansowych pozwala wyróżnić kapitalizm inwestycyjny i kasynowy.

Barnes określił dwie fazy kapitalizmu: niedoboru i nadmiaru’ Faza niedoboru dotyczy pierwszej połowy XX wieku, kiedy to panowała bieda ze względu na niskie wynagrodzenia, długi czas pracy oraz wszechobecne bezrobocie. W tej fazie kapitalizmu istniała obfitość ziemi, surowców i siły roboczej, a brakowało kapitału. Dlatego też rozwój ustawodawstwa i praktyk został pokierowany w ten sposób, że kapitałowi nadano charakter nadrzędny. Po II wojnie światowej w latach 50. XX wieku kapitalizm wkroczył w nową fazę. W kapitalizmie nadmiaru problem nie dotyczył już trudności zaspokojenia popytu, lecz znalezienia klientów. Istniejący nadmiar

${ }^{4}$ A. Smith, An Inquiry into the Nature and Causes of the Wealth of Nations, A Penn State Electronic Classics Series Publication, The Pennsylvania State University 2005, s. 584.

5 D. Piekenbrock., Gabler Kompakt-Lexikon: Volkswirtschaftslehre, GWV Fachverlage GmbH, Wiesbaden 2009, s. 215

6 V. Happe, G. Horn, K. Otto, Das Wirtschaftslexikon: Begriffe, Zahlen, Zusammenhänge, J.H.W. Dietz Nachf. GmbH, Bonn 2009, s. 176.

P. Barnes, Capitalism 3.0 - A guide to reclaiming the commons, Berrett-Koehler Publ., San Francisco 2006, s. 23 
kapitału został wykorzystywany do spekulacji. Niedoborem z kolei stało się środowisko naturalne. Kapitalizm nadmiaru nie był jednak jednolity. Biedniejsza część społeczeństwa nadal cierpiała z powodu niedoboru dóbr podstawowych, a niedobór u lepiej usytuowanej klasy średniej objawiał się brakiem czasu, przyjaźni, przynależności do wspólnoty. Tabela 1 pokazuje różnice między tymi fazami kapitalizmu.

Tabela 1. Kapitalizm niedoboru i nadmiaru

\begin{tabular}{|l|l|l|}
\hline & \multicolumn{1}{|c|}{ Kapitalizm niedoboru } & \multicolumn{1}{|c|}{ Kapitalizm nadmiaru } \\
\hline Skala & lokalna & globalna \\
\hline Popyt i podaż & popyt jest większy niż podaż & podaż jest większa niż popyt \\
\hline Koszty zewnętrzne & niskie & wysokie \\
\hline Reklama & niewielka & wszechobecna \\
\hline Wartość marginalna dodatkowej siły roboczej & wysoka & niska \\
\hline Niedobory & zagregowany kapitał & $\begin{array}{l}\text { czas, środowisko naturalne, } \\
\text { dochód, przyjaźń, wspólnota }\end{array}$ \\
\hline
\end{tabular}

Źródło: P. Barnes, Capitalism 3.0 - A guide to reclaiming the commons, Berrett-Koehler Publ., San Francisco 2006, s. 24.

Rozpiętości dochodowe są bardzo duże, przykładowo w krajach anglosaskich, Ameryce Środkowej i Południowej, Chinach, zaś mniejsze w krajach skandynawskich.

Sukcesem stała się społeczna gospodarka rynkowa, zwana również ordoliberalizmem, opracowana przez szkołę fryburską i stosowana przez L. Erharda w Republice Federalnej Niemiec po zakończeniu II wojny światowej. Jej zadaniem było połączenie konkurencyjnych struktur rynku z odrodzeniem się klasy średniej. „Realizację tych celów wspierała demokratyzacja struktur politycznych, działania na rzecz przekształcenia niemieckiego społeczeństwa w społeczeństwo obywatelskie, w którym wolność jednostki znajduje trwałe oparcie we własności prywatnej, stabilizacja cen i utrzymywanie równowagi gospodarczej. Elementem uzupełniającym program społecznej gospodarki rynkowej była ochrona socjalna dla najuboższych"8.

Ekstremalną formę kapitalizmu nadmiaru przybrał od lat 70. turbokapitalizm. „Nazwa ta wskazuje na nową jakość, polegającą na szybkości obiegu kapitału i związanym z nią wzroście jego mocy. [...] Nie powstałby on również bez drugiego zjawiska w życiu gospodarczym, a mianowicie wirtualizacji świata finansów. Oba zjawiska doprowadziły ostatecznie do dominacji giełdy nad bankami, powstania nowych postaci instrumentów finansowych, skutkujących samonamnażaniem się

\footnotetext{
${ }^{8}$ http://biznes.pwn.pl/index.php?module=haslo\&id=3978380 (14.06.2012).
} 
wirtualnej wartości, a w ostateczności do dominacji sektora finansowego nad realną gospodarką"

\section{Patologie kapitalizmu}

Jedną z patologii kapitalizmu jest degradacja środowiska naturalnego. Warto wspomnieć, ze również inne systemy gospodarcze miały na nie negatywny wpływ. Jednak poprzez globalizację i rozwój informatyczno-techniczny charakterystyczne dla ostatnich dziesięcioleci, proces degradacji przyrody stał się w krótkim czasie bardziej intensywny oraz łatwiejszy do zaobserwowania i zmierzenia. Wyniki wpływu tego systemu na zmiany w środowisku naturalnym można stwierdzić na podstawie raportu sporządzonego przez Millennium Ecosystem Assessment. Według niego 60\% ekosystemu światowego uległo degradacji lub jest wykorzystywane w sposób niezrównoważony ${ }^{10}$. Faktyczny koszt degradacji środowiska naturalnego jest trudny do zmierzenia. Dostępne dane potwierdzają dalsze postępowanie tego procesu, który ma ogromny wpływ na dalszy los ludzkości, ponieważ potencjalnymi konsekwencjami są powodzie, susze, wzrost poziomu morza, ocieplenie klimatu, tworzenie się martwych stref w obszarach nadmorskich, gwałtowny spadek rybołówstwa czy też pojawienie się nowych chorób.

Można się zastanawiać, kto ponosi odpowiedzialność za niszczenie ekosystemów i różnorodności gatunkowej. Jedno jest pewne: za większość zniszczeń odpowiedzialna jest niewielka grupa bogatych, zaś konsekwencje odczuwa znaczna część biednych obywateli. Nadmierna konsumpcja będąca produktem kapitalizmu nadmiaru ma duży udział w degradacji środowiska naturalnego, a przemysł zależy od kończących się zasobów ropy naftowej i gazu. Wartość środowiska w kalkulacji kosztów korporacji nie jest najczęściej brana pod uwagę albo określana jako zerowa.

Kolejną patologią kapitalizmu jest wzrost przepaści między biednymi i bogatymi. Na przełomie wielu dziejów w rozwoju ludzkości brakowało równowagi w tym aspekcie. Nadzieję na zmianę w tej kwestii przyniósł rozwój, który nastąpił po zakończeniu II wojny światowej. Przyczynił się on do rozprzestrzenienia dobrobytu na wiele grup społecznych. Wzrost gospodarczy w ciągu ostatnich sześćdziesiąt lat miał właściwie nieprzerwaną tendencję wzrostową. „Nawet w Stanach Zjednoczonych

\footnotetext{
9 G. Szulczewski, Etyka wobec współczesnego kryzysu ekonomicznego, w: Nauki społeczne wobec kryzysu ekonomicznego, red. J. Osiński, Oficyna Wydawnicza SGH, Warszawa 2009, s. 69.

10 Millennium Ecosystem Assessment, Ecosystems and human well-being - Synthesis, Island Press, Washington 2005, s. 1.
} 
w wyniku zapoczątkowanej przez Franklina Roosevelta polityki Nowego Ładu doszło w latach 50. i 60. do znacznego zmniejszenia rozpiętości ekonomicznych i poprawy jakości życia społecznego (pomijając tu konflikty na tle rasowym)" ${ }^{11}$. Trzeba jednak przyznać, że wiele $\mathrm{z}$ reform wprowadzonych $\mathrm{w}$ ramach programu Nowego Ładu miało charakter bardziej socjalistyczny niż kapitalistyczny. Dla przykładu stworzenie w 1934 roku National Housing Act i Federal Housing Authority (FHA) ${ }^{12}$ pozwoliło przydzielić sześćdziesięcioletnie nisko oprocentowane kredyty dla władz lokalnych na budowę domów komunalnych. Mieszkania komunalne oferowano rodzinom o niskich dochodach za niskie, regulowane czynsze. Do 1941 roku wybudowano 120 tys. mieszkańn ${ }^{13}$.

Zwrot w kierunku tych zmian przyniosły kolejne ustawy: z roku 1956 Multi Bank Holding Company Act ${ }^{14}$ oraz z roku 1960 One Bank Holding Company Act ${ }^{15}$, liberalizujące działalność bankową. Pozwolono na prowadzenie działalności bankowej przez organizacje niebędące bankami. Umożliwiło to bankom tworzenie spółek córek niepodlegających nadzorowi bankowemu. Ponadto powstanie w latach 60 . $\mathrm{XX}$ wieku rajów podatkowych umożliwiło zarówno zamożnym obywatelom, jak i korporacjom odprowadzanie podatków poza granicami ich kraju. Według raportu Banku Światowego i ONZ z roku 2007 państwa tracą rocznie około 500 mld dol. w wyniku uchylania się obywateli i firm od płacenia podatków ${ }^{16}$. Podatki od działalności gospodarczej przedsiębiorstw, które w ten sposób nie trafiają do odpowiednich państw jako odbiorców, muszą być skompensowane poprzez pomoc rozwojową dla krajów rozwijających się lub przez zaciąganie przez biedne państwa kolejnych kredytów ${ }^{17}$. Ten problem dotyczy także państw bogatych, w których przyczynia się on do powiększania się nierówności społecznej. Janusz Reykowski uważa, że proces ten jest wynikiem ofensywnej polityki neoliberalnej prowadzonej przez Margaret Thatcher i Ronalda Reagana. Brakowało w ich polityce mechanizmów automatycznie znoszących nierówności, przy jednoczesnym zachowaniu efektywności ekonomicznej, sprzyjającej wzrostowi gospodarczemu, a w konsekwencji dających każdemu obywatelowi szanse awansu ekonomicznego, społecznego, edukacyjnego i kulturalnego.

\footnotetext{
11 http://www.przeglad-tygodnik.pl/pl/artykul/kapitalizm-do-naprawy (7.06.2012).

$12 \mathrm{http} / / /$ www.hud.gov/offices/adm/about/admguide/history.cfm (12.06.2012).

13 S. Sztaba, wykład pt. Kryzys finansowy 2007, Warszawa 2012, s. 20.

$14 \mathrm{http}: / /$ www.fdic.gov/regulations/laws/rules/6000-300.html\#fdic6000sec2a (12.06.2012).

$15 \mathrm{~J}$. William, The administration of the bank merger and holding company acts: confusion compounded, „Virginia Law Review” 1965, 51 (8), s. 1517.

16 World Bank, ONZ, Stolen Asset Recovery (StAR) Initiative: Challenges, Opportunities, and Action Plan, Washington 2007, s. 9.

17 Tax Justice Network, Information zum Thema Steuergerechtigkeit: Rechnungslegung nach Ländern. Für mehr Transparenz transnationaler Konzerne, 2008, s. 2.
} 
„Obecne formy demokratycznego kapitalizmu sprzyjają temu, że najsilniejsi, najwyżej stojący mogą zagarniać dla siebie najwięcej” ${ }^{18}$.

Wynikiem rosnącej przepaści między najbogatszymi a najbiedniejszymi i masowo występującego problemu bezrobocia jest zjawisko wykluczenia społecznego dotyczące osób, rodzin lub grup ludności, które „żyją w niekorzystnych warunkach ekonomicznych [...], zostają dotknięte niekorzystnymi procesami społecznymi, wynikającymi z masowych i dynamicznych zmian rozwojowych, np. dezindustrializacji, kryzysów, gwałtownego upadku branż czy regionów, [...] doświadczają przejawów dyskryminacji, zarówno wskutek niedorozwoju właściwego lub ustawodawstwa, jak i kulturowych uprzedzeń oraz stereotypów [...], a także są przedmiotem niszczącego działania innych osób, np. przemocy, szantażu, indoktrynacji”" ${ }^{19}$.

W wymiarze międzypaństwowym problemy te uwypuklają nierównowagi globalne, które przekładają się na wskaźniki ekonomiczne. W krajach rozwiniętych występował znaczny deficyt na rachunku obrotów bieżących, a w krajach rozwijających się dominowały nadwyżki handlowe. Przepływy kapitału między krajami wysoko rozwiniętymi i rozwijającymi się są także niesymetryczne. Do krajów rozwijających się napływa z krajów rozwiniętych strumień prywatnych inwestycji bezpośrednich, przyspieszając wzrost gospodarczy w tym regionie. Do krajów rozwiniętych napływa strumień inwestycji banków centralnych krajów rozwijających się. Wywołuje to efekt majątkowy polegający zwiększeniu popytu przez społeczeństwa krajów rozwiniętych ze względu na wzrost wartości majątku (ziemi, nieruchomości, akcji), co pozwala podtrzymywać wzrost gospodarczy na minimalnym poziomie. Duża podaż pieniądza i rosnące ceny aktywów tworzą sprzyjające warunki do nadmuchiwania baniek spekulacyjnych.

\section{Geneza finansowych korporacji transnarodowych}

Korporacje jako jedna $\mathrm{z}$ form podmiotów gospodarczych są ważnym produktem kapitalizmu. Są to spółki notowane na giełdzie, które dążą do maksymalizacji zysku akcjonariuszy. Ich celem jest: zdobycie nowych rynków zbytu, osiąganie efektów skali, dominacja na rynku oraz osiąganie korzyści podatkowych. Pierwsze korporacje zaczęły powstawać w XVIII wieku w Stanach Zjednoczonych i Wielkiej Brytanii.

\footnotetext{
$18 \mathrm{http}: / /$ www.przeglad-tygodnik.pl/pl/artykul/kapitalizm-do-naprawy (7.06.2012).

19 J. Hausner, Ekonomia społeczna jako kategoria rozwoju, Raport „W poszukiwaniu polskiego modelu ekonomii społecznej", Małopolska Szkoła Administracji Publicznej Akademii Ekonomicznej w Krakowie, Kraków 2007, s. 13.
} 
W czasach, gdy Adam Smith napisał Badania nad natura i przyczynami bogactwa narodów, główną formą podmiotów gospodarczych były spółki składające się z małych grup ludzi, którzy się znali i prowadzili wspólne interesy. Fakt sprzedawania udziałów własnej firmy osobom trzecim w ówczesnych czasach widziany był jako potencjalna możliwość do pojawienia się oszustwa. Ponadto liczne skandale wspierały takie przekonanie. W wyniku wzrostu skali przedsięwzięć, industrializacji, nadmiaru pracowników na rynku pracy wynikającego z eksplozji liczby ludności zmieniła się struktura produkcji ${ }^{20}$. Małe spółki i zakłady rzemieślnicze nie były w stanie zgromadzić dużych sum kapitału, a pozytywnym aspektem korporacji okazała się możliwość pozyskania nowych źródeł kapitału od osób trzecich. Dodatkowo nowo powstające prawo ograniczyło odpowiedzialność inwestorów do wysokości zainwestowanego kapitału ${ }^{21}$. Początkowo korporacje były kontrolowane przez organy państwowe, np. poprzez administrację dzierżaw, pozwoleń zależnie od rodzaju prowadzonych interesów. Wraz ze wzrostem ich znaczenia korporacje otrzymywały coraz więcej wolności. W połowie XIX wieku mogły one angażować się w dowolną działalność gospodarczą oraz kupować inne spółki. W 1886 roku decyzją Sądu Najwyższego Stanów Zjednoczonych, powołując się na 14 poprawkę do konstytucji, zrównano prawa korporacji z prawami przysługującymi dotychczas tylko ludziom $^{22}$. Poszerzyło to przywileje korporacji, np. gwarantując im równe traktowanie wobec prawa oraz nienaruszalność prawa do życia, wolności i własności prywatnej. Można zatem wnioskować, że korporacje miały prawa i przywileje posiadane przez ludzi, ale w wyniku ograniczenia odpowiedzialności i uzyskania znacznej siły ekonomicznej oraz politycznej nie obligowało się ich do wywiązywania się z obowiązków, jakie posiadał normalny obywatel. Korporacje co prawda nie mają prawa do głosowania, ale dysponując ogromnymi środkami pieniężnymi, mogą zatrudniać specjalistów od lobbingu, wpływać na opinię publiczną, a sponsorując polityków, wpływać na ich decyzje.

W początkowej fazie kapitalizmu z powodu braku kapitału rozwój ustawodawstwa i praktyk gospodarczych przyczynił się do nadania kapitałowi charakteru nadrzędnego. Na tym etapie założono wiele korporacji finansowych, które obecnie należą do największych na świecie:

- Halifax Bank of Scotland, Szkocja - rok założenia 169523,

20 K.D. Grüske, F. Schneider, Wörterbuch der Wirtschaft, Alfred Kröner Verlag, Stuttgart 2003, s. 260.

21 P.A. Gilje, The Rise of Capitalism in the Early Republic, ,Journal of the Early Republic”, Special Issue on Capitalism in the Early Republic, University of Pennsylvania 1996, 16 (2), s. 165.

22 http://supreme.justia.com/cases/federal/us/118/394 (8.06.2012).

23 http://www.scotbanks.org.uk/banking_history.php (9.06.2012). 
- Bank of New York Mellon, USA - rok założenia $1784^{24}$,

- State Street Trust Company, USA - rok założenia $1792^{25}$,

- JP Morgan, USA - rok założenia $1799^{26}$,

- Goldman Sachs, USA - rok założenia $1869^{27}$,

- Deutsche Bank, Niemcy - rok założenia $1870^{28}$,

- Salomon Brothers, USA - rok założenia $1910^{29}$.

Steiner stwierdził, że po podpisaniu traktatu wersalskiego po II wojnie światowej kwestie gospodarcze świata zdominowane zostały przez Stany Zjednoczone i Wielką Brytanię, które też powinny ponosić odpowiedzialność za ich kształt ${ }^{30}$.

\section{Wymiar społeczny działalności międzynarodowych instytucji finansowych}

Pod koniec XX wieku skala ekonomicznego i politycznego wpływu korporacji finansowych rozprzestrzeniła się na cały świat. Początkowo rola banków w gospodarce rozumiana jako uczestnika $\mathrm{w}$ procesie kreacji pieniądza i społecznym podziale pracy, pośrednika finansowego oraz instytucji alokującej i transformującej środki uległa znaczym modyfikacjom ${ }^{31}$. Ustawodawstwo międzynarodowe inicjowane przez USA poszerzyło prawa własnościowe korporacji oraz zmniejszyło suwerenność państw do dywersyfikacji narodowych regulacji prawnych. Taka przychylność wobec tych podmiotów gospodarczych zaowocowała osiągnięciem znacznej hegemonii

w skali globalnej. Dla przykładu ustawa Gramma-Leacha-Blileya z 1999 roku zastąpiła uchyloną ustawę Glassa-Steagalla z 1933 roku rozdzielającą klasyczną bankowość (polegającą na przyjmowaniu depozytów i udzielaniu kredytów) od bankowości inwestycyjnej ${ }^{32}$. Umożliwiło to tworzenie konglomeratów finansowych, świadczących wiele rodzajów usług finansowych. Następnie Commodity Futures

\footnotetext{
${ }^{24} \mathrm{http} / / / \mathrm{www} \cdot$ bnymellon.com/about/history/index.html (9.06.2012).

$25 \mathrm{http} / /$ www.statestreet.com/wps/portal/internet/corporate/home/aboutstatestreet/corpora te overview/history/!ut/p/c4/04_SB8K8xLLM9MSSzPy8xBz9CP0os3i_0CADCydDRwP_IGdnA08Tc38fI NvY3dFEPzglNd7FVb8g21ERAAgwk1M!/ (9.06.2012).

${ }^{26} \mathrm{http}: / /$ www.jpmorgan.com/pages/jpmorgan/about/history (9.06.2012).

$27 \mathrm{http}: / /$ www.fundinguniverse.com/company-histories/the-goldman-sachs-group-inc-history/ (9.06.2012).

${ }^{28}$ https://www.deutsche-bank.de/de/media/DB_geschichte_meilensteine_120dpi_de.pdf (10.06.2012).

$29 \mathrm{http}: / / \mathrm{www}$.fundinguniverse.com/company-histories/salomon-inc-history/ (9.06.2012).

30 C. Houghton Budd, Finance at the threshold - rethinking the real and financial economies, Gower Publ. Comp., Farnham-Burlington 2011, s. 15.

${ }^{31}$ S. Flejterski, B. Świecka, Finanse i bankowość, Wydawnictwo Economicus, Szczecin 2004, s. 35.

32 http://www.mpls.frb.org/publications_papers/pub_display.cfm?id=3534 (10.06.2012).
} 
Modernization Act z roku 2000 roku wyłączała rynki międzybankowe z postanowień wydanej w 1936 roku ustawy Commodity Exchange Act regulującej handel na giełdach surowcowych ${ }^{33}$. „Ustawa ta dawała agencjom federalnym możliwość ustalania limitów ograniczających możliwości spekulacji, która wpływałaby destabilizująco na ceny żywności i surowców. Na giełdach terminowych limity te są do dzisiejszego dnia często stosowane. Deregulacja rynków międzybankowych osłabiła nadzór nad systemem bankowym, stała się także ważną przyczyną globalnego wzrostu cen żywności i surowców"34. Ponadto kryzys finansowy z roku 2008 podkreślił wrażliwość systemu finansowego na wstrząsy i nierównowagi w gospodarce i wobec tego konieczność wprowadzenia „adekwatnych rozwiązań instytucjonalno-prawno-organizacyjnych" ${ }^{35}$, ograniczajacych pojawienie się spekulacji na rynkach finansowych.

W konsekwencji zagadnienie społecznej odpowiedzialności instytucji finansowych stało się bardzo ważnym tematem we współczesnej gospodarce światowej. Według Dziawgo „znaczna część spółek giełdowych nie ma wyraźnego właściciela (gospodarza, czyli akcjonariuszy), a przecież najlepszym nadzorcą nie jest nikt inny, jak właściciel. Niestety, ład instytucjonalny świata finansów dryfuje ku rozmyciu kategorii »własność«, która jest przecież fundamentem gospodarki rynkowej”36. Można z tego wnioskować, że rozpraszanie własności skutkuje rozpraszaniem odpowiedzialności, czyli w konsekwencji jej brakiem. Warto przypomnieć, że podstawowym celem działalności instytucji finansowych jest nadal generowanie zysku. Pytanie, w jaki sposób osiąga się oczekiwane wyniki, jest raczej drugorzędne. W związku z tym, że odeszliśmy od wymiany barterowej, a pieniądz stał się od wieków powszechnie akceptowanym środkiem płatniczym o rosnącym znaczeniu, instytucje finansowe zyskiwały na sile. Należy również stwierdzić, że ten system funkcjonował sprawnie przez ostatnie kilka wieków. Dopiero pod koniec lat 90. XX wieku w wyniku bardzo szybkiego rozwoju działalności inwestycyjnej banków, stosowania matematycznych modeli usprawniających zarządzanie portfelem inwestycyjnym oraz powstawania skomplikowanych instrumentów pochodnych nastąpiły znaczne zmiany. Stosowanie derywatów umożliwiło osiąganie zysków nawet podczas spadających kursów na giełdach. Rozwój ten wzmocnił pozycję sektora finansowego na świecie, przyspieszył wymianę informacji, dokonywanie transakcji, uwypuklił skutki oddzielenia go od gospodarki realnej i skrócił czas występowania kolejnych etapów

33 http://www.sec.gov/about/laws/cfma.pdf (10.06.2012).

34 S. Sztaba, wykład pt. Kryzys finansowy 2007, op.cit., s. 27-28.

35 A. Alińska, Rola i pozycja sieci bezpieczeństwa finansowego w utrzymaniu stabilności systemu finansowego, w: Polityka monetarna i fiskalna a stabilność sektora finasowego, CeDeWu, Warszawa 2012, s. 30.

${ }^{36}$ L. Dziawgo, Współczesny biznes bankowy - patologiczne otoczenie, „ekonomia polityczna” oraz ład monetarno-instytucjonalny rynku finansowego jako zagrożenie dla bankowości, „,Bankowy Fundusz Gwarancyjny, Bezpieczny Bank" 2011, 3 (45), s. 15. 
cyklów koniunkturalnych. Znaleziono nowe obszary, które gwarantowały osiąganie ogromnych stóp zwrotu $z$ inwestycji np. na rynku nieruchomości, surowców naturalnych czy produktów żywnościowych, a także w Azji w wyniku wzbogacania się klasy średniej krajów rozwijających się $e^{37}$. Wzorcowym realizatorem tej strategii był Deutsche Bank, który w ciągu ostatnich dziesięciu lat stał się jednym z najważniejszych banków inwestycyjnych na świecie. Podobnie jak inni światowi gracze stosował spekulacyjne transakcje, nie informując swoich klientów o rzeczywistym ryzyku. W wyniku niekompetentnych porad oraz złych założeń odnośnie do rozwoju rynków przyczynił się do utraty przez wielu obywateli oszczędności emerytalnych czy nieruchomości. Naraził wiele miast, takich jak: Mediolan, Hagen, Pforzheim, Würzburg, Neuss, Solingen i region Toskanii na bardzo duże straty. Konsekwencje tych działań są coraz bardziej odczuwalne przez podatników i lokalne społeczności, a Deutsche Bank dobrze zarabiał na tych transakcjach ${ }^{38}$.

Problem działalności korporacji finansowych objawia się w tym, że w rzeczywistości nie są one ludźmi, jak stanowi prawo amerykańskie, lecz podmiotami gospodarczymi skierowanymi na bezwzględne generowanie zysku dla udziałowców. Poza tym korporacje nigdy nie śpią i nie zwalniają tempa, a także dobrowolnie nie osiągają poziomu zysków, który je satysfakcjonuje. Wytwarzają one jednocześnie koszty zewnętrzne adekwatne do ich rozmiaru. W wyniku ogromnego wpływu lobbingu silnych korporacji bankowych stały się powszechne nastepujące dogmaty: siłą napędową wzrostu gospodarczego są wielkie i silne kapitałowo korporacje bankowe, „zbyt wielki lub zbyt ważny aby upaść, oraz wszechobecne fuzje i przejęcia wspomagające efektywność organizacyjną. W takim systemie pieniężno-finansowym banki nie są motywowane do realizowania idei społecznie odpowiedzialnego biznesu bankowego" ${ }^{\prime 39}$. Dlatego wymiar społeczny działalności międzynarodowych instytucji finansowych charakteryzuje się tym, że był on zbyt długo ignorowany. A wadą raportów odpowiedzialności społecznej biznesu, które charakteryzują się odpowiedzialnością pozytywną - czyli sprawozdawczością dobrowolnie podejmowaną, w zgodzie z ideą CSR, jest traktowanie przez wiele przedsiębiorstw tych publikacji jako platformy marketingowej. Wobec tego zrozumiałe jest to, że nikt dobrowolnie nie umieści w takim sprawozdaniu informacji, które mogłyby zaszkodzić jego wizerunkowi oraz nie ustosunkowuje się do kwestii spornych. Trzeba jednak przyznać, że mimo

${ }_{37}$ K.M. Pniewska, Społeczna odpowiedzialność wobec wyzwań sektora bankowego w okresie zawirowań na rynkach, w: Stabilność systemu finasowego - instytucje, instrumenty, uwarunkowania, CeDeWu, Warszawa 2012, s. 300.

38 Verzockt und verklagt Die guten Geschäfte der Deutschen Bank, http://www.youtube.com/ watch?v=Wr2DBrzEUsk (12.06.2012).

${ }^{39}$ D. Korenik, Czy społeczna odpowiedzialność biznesu bankowego to konieczność, w: Eseje o stabilności finansowej, red. A. Alińska, CeDeWu, Warszawa 2012, s. 30. 
występujących jeszcze niedoskonałości zarysowujący się wyraźny trend wzrostowy inwestycji społecznie odpowiedzialnych wskazuje na długotrwały proces „prowadzący do strukturalnej zmiany funkcjonowania świata finansowego" ${ }^{\text {" }}$, a nie na przejaw wynikający z aktualnie panującej mody na to zjawisko.

\section{Kryzys finansowy szansą na zmianę obecnej formy kapitalizmu}

Kryzys finansowy roku 2007 zburzył mit, że duże koncerny finansowe mające dwieście lat tradycji nie mogą zbankrutować. Doprowadził do tego, że dotychczas krytykowane interwencje państwowe w gospodarkę wolnorynkową stały się jedynym rozwiązaniem ratującym system bankowy i zależne od niego gałęzie przemysłu. Wywołał on także liczne debaty, które małymi krokami wprowadzają regulacje prawne działalności inwestycyjnej, bankowej czy kontrolowania poziomu wynagrodzeń na najwyższych szczeblach menedżerskich. Nie przyniosły one jeszcze za sobą znacznych zmian strukturalnych. Zmiany te jednak powoli następują w świadomości społecznej. Ciekawe jest także, że w wywiadzie udzielonym telewizji Phoenix w dniu 13 maja 2012 roku przez prezesa Deutsche Bank Josefa Ackermanna widać było zmiany w percepcji odpowiedzialności wobec świata przez reprezentanta klasycznego nurtu finansów. Powiedział on, że w konsekwencji kryzysu standardy, jakie obowiązywały nawet dziesięć lat temu, nie znajdują obecnie akceptacji społecznej ${ }^{41}$ i wobec tego należy na nowo zdefiniować rolę sektora finansowego i instytucji finansowych, nakłaniając je do uwzględniania kwestii społecznych. Dla przykładu on sam przyczynił się do zerwania umowy z firmą produkującą bomby i zadeklarował niewchodzenie $\mathrm{w}$ nowe przedsięwzięcia związane z branżą zbrojeniową oraz zlecił zbadanie wpływu usług inwestycyjnych na poziom cen produktów żywnościowych na rynkach światowych. Dodał, że „żaden interes nie jest tego wart, by ryzykować dla niego dobre imię Deutsche Banku”. Pojawia się tylko pytanie: jak mają się obietnice i slogany Ackermanna, który ustąpił 31 maja 2012 roku ze stanowiska prezesa banku, do rzeczywistych praktyk realizowanych przez Deutsche Bank? Najnowsza afera dotycząca tego banku, w której jeden pracownik otrzymał 80 mln euro premii,

40 A. De Wolf, Investissments responsable (IR), effet de mode ou évolution naturelle?, „Swiss Global Finance Magazine” 2007, 11 (3).

${ }^{41}$ „Forum Manager”, program wyemitowany przez telewizję Phoenix w 13 maja 2012. 
nakreśla działalność odległą od rzeczywistości ${ }^{42}$. Warto dodać, że ten pracownik uwikłany był w skandal stóp LIBOR.

Faktem jest, że taka refleksja stanowi zalążek zmiany. Kryzys finansowy z roku 2007 przyczynił się do tego, że instytucje finansowe generalnie niezobligowane statutowo do tego modyfikują standardy społecznie odpowiedzialnego biznesu i wykorzystują je w tworzeniu swoich produktów. Według prof. Korenik banki powinny spełniać jednocześnie trzy funkcje: być „prodochodowe, bezpieczne ekonomicznie i autentycznie potrzebne dla gospodarki realnej" ${ }^{33}$. Produkty i usługi bankowe z pewnością nie są jeszcze doskonałe, ale zdecydowanie nakreślają kierunek dalszego ich rozwoju. Świadomość klientów i zmian zachowań konsumenckich, a także coraz łatwiejsze zrzeszanie się ich nawet za pomocą Facebooka świadczą o tym, że ten proces jest nieodwracalny i skazany na profesjonalizację.

Konieczność wprowadzenia modyfikacji aktualnej formy kapitalizmu widzą także współcześni politycy, wskazując m.in. na potrzebę zmiany podejścia do wyrównania przepaści międzyludzkich i nierówności poziomów życia.

Celem polityki gospodarczej po kryzysie finansowym końca pierwszej dekady XXI wieku powinno być przywrócenie nadrzędnej roli człowieka w gospodarce. Należałoby również uniknąć paniki bankowej poprzez zlikwidowanie niedoborów płynności, nierówności społecznych oraz przywrócenie państwowym instytucjom nadzorczym funkcji kontrolnej nad sektorem finansów. Ten proces powinien być oparty na odbudowie zaufania gospodarstw domowych do instytucji finansowych oraz między samymi tymi instytucjami i odebrania im narzędzi do tworzenia kolejnych baniek spekulacyjnych.

Ciekawe jest też, czy ostatni kryzys światowy przyczyni się do realizacji wizji Marksa i Schumpetera, którzy przewidywali koniec kapitalizmu? Według Marksa upadek kapitalizmu zostałby wywołany paradoksem istniejącym między społecznym charakterem produkcji a prywatnym przywłaszczaniem sobie jego wyników, po czym nastałby socjalizm. Według Schumpetera koniec kapitalizmu wynikać będzie z konsekwencji jego sukcesów, ponieważ kapitalizm prowadzi co prawda do wzrostu produktu społecznego, ale ma on tendencję malejącą, spółki prowadzone są przez menedżerów, którzy wykazują małe zainteresowanie utrzymaniem tego systemu, na skutek czego postać dynamicznego przedsiębiorcy okaże się zbędna w procesie „kreatywnego zniszczenia”"4.

\footnotetext{
42 http://www.n-tv.de/wirtschaft/Deutsche-Bank-will-klagen-article10144336.html (18.02.2013).

43 D. Korenik, Refleksja na temat społecznej odpowiedzialności banku komercyjnego, „Bankowy Fundusz Gwarancyjny, Bezpieczny Bank" 2011, 3 (45), s. 23.

${ }^{44}$ Der Brockhaus, op.cit., s. 319.
} 


\section{Podsumowanie}

Zorganizowane mechanizmy rynkowe istnieją dzięki funkcjonującym instytucjom państwowym gwarantującym respektowanie oraz przestrzeganie ustanowionych praw i odpowiedzialności. W związku z tym, że prawa własności są zdobyczą cywilizacyjną, demokracja i wdrażanie gospodarki wolnorynkowej będą szeroko akceptowane, gdy klasa średnia będzie silna.

W kapitalizmie to właśnie kapitał odgrywa najważniejszą rolę, a jego podmioty skierowane są na stałe pomnażanie zysku. Kapitalizm przyczynił się do poprawy standardu życia krajów kapitalistycznych. Jednakże nadmiar kapitału leży w rękach kilkuprocentowej populacji świata, która decyduje o losach świata. Niestety, poprawa ta odbywa się kosztem najsłabszych obywateli oraz regionów świata, wobec czego następuje pogłębianie się nierównowagi w różnych dziedzinach, prowadząc do degradacji środowiska naturalnego oraz wykluczenia wielu grup społecznych w skali narodowej i globalnej.

Zmiany ustawodawcze i polityczne dotyczące życia gospodarczego przeprowadzone w ubiegłym stuleciu doprowadziły do tego, że kapitał przejął władzę nad człowiekiem. Te reformy pozwoliły rynkom kapitałowym oddalić się od gospodarki realnej i osiągać zyski poprzez tworzenie baniek spekulacyjnych. Podstawową wadę polegającą na bezwzględnym dążeniu do krótkoterminowych zysków uwypuklił ostatni kryzys finansowy. W wyniku globalizacji nastąpiła ważna zmiana strukturalna wywołana znaczną koncentracją gospodarczą. Nastąpił właściwie zanik konkurencji doskonałej, a oligopole są podstawowym modelem rynkowym. Większość branż (także rynek finansowy) zdominowana jest przez 5-6 korporacji, które dzielą między sobą rynek światowy.

Uczestnicy regionalnych rynków nie mogą sobie pozwolić na tworzenie produktów czy usług szkodzących ludziom lub środowisku, ponieważ zła reputacja przyczyniłaby się do utraty klientów, a w konsekwencji do bankructwa. Według mnie rozmiar finansowych korporacji transnarodowych i ich obecność na większości rynków światowych gwarantuje im idealną dywersyfikację ryzyka swojej działalności oraz przyzwala im na nieponoszenie odpowiedzialności za swoje działania. 


\section{Social significance of financial corporations in capitalism}

In capitalism the capital plays superior role. Financial markets and financial corporations have a special and fundamental place in it due to their importance for market economy and economic growth. For a long time the pathologies of capitalism like degradation of environment, increasing gulf between rich and poor, social exclusion and global disequilibrium that capitalism is responsible for were ignored. The explanation was that the market will solve all the problems. Unfortunately, the market isn't perfect. A good example of market imperfections is the use of excess capital for speculation. Therefore it is necessary to redefine the role of financial corporation so it includes social matters.

\section{La dimension sociale des sociétés financières dans le système capitaliste}

La capitale est d'une importance primordiale dans le capitalisme. Les marchés financiers et les sociétés financières jouent un rôle particulier dans ce système, parce qu'ils sont fondamentaux pour le développement de léconomie de marché et pour la croissance économique. Les pathologies associées à ce système, qui ont été longtemps négligées, comprennent: la dégradation de l'environnement, lécart croissant entre les plus riches et les plus pauvres, l'exclusion sociale et les déséquilibres mondiaux. Cela a été expliqué par le fait que c’est le marché qui aurait dû tout régler. Malheureusement, le marché a aussi ses inconvénients, dont le bon exemple est l'excédent du capital utilisé pour spéculer. Par conséquent, il est recommandé de redéfinir le rôle des sociétés financières qui devrait envisager les questions sociales. 